\title{
EDITORIAL
}

\section{Antonio Marín: un hombre que creyó en las enfermeras}

\author{
J. Javier Soldevilla-Agreda \\ Director de Gerokomos
}

Lamentaría que la tribuna que prologa una producción científica como la que recrea las páginas de GEROKOMOs se convierta en habitual obituario, por lo que supone de pérdida y despedida, pero qué mejor espacio elegir para declamar la talla, cercanía, buen hacer y humildad de Tońo Marín. Alejado en vida de homenajes y reconocimientos, hoy estas líneas quieren dirigirse a exaltar su memoria desde las páginas que han recogido frutos de su siembra y fe, Ciencia y experiencias de las enfermeras gerontológicas que le rodearon y en las que nuestro amigo creyó.

A Tońo lo conocía desde hace al menos veinticinco ańos cuando el movimiento de nuestra enfermería de la vejez balbuceaba, cuando el escenario de la atención al mayor en nuestro país estaba solo en hilvanes, cuando las iniciativas y los recursos pensados y puestos al alcance de los mayores eran pocos y básicos, salvo, ya desde entonces, los manados desde el seno de la Diputación Foral de Álava, del área técnica de su Departamento de Asuntos Sociales en donde las propuestas, la creatividad y oportunidad en el diseño de los recursos marcaban diferencias, y Tońo como timonel en un modelo asistencial donde él, personalmente, consideró la enfermería como una pieza insustituible en la que se podía confiar y delegar responsabilidades y competencias de gestión y asistenciales inusuales hasta la fecha. Esa forma de hacer, el desarrollo alcanzado, la calidad de los servicios prestados, brillaba con luz propia y diferencial en un país ralentizado en el desarrollo de un plan gerontológico acorde con las necesidades y al ritmo que una población envejeciente demandaba. Álava era por ello motivo de envidia. Envejecer en sus tierras tenía un plus de opciones a recursos hasta entonces difícilmente imaginables. La apuesta de los políticos por la exigencia de los ciudadanos y una excelente dirección técnica de ese entramado se conjugaron, se fundieron, y Tońo Marín fue una pieza clave en ese admirable panorama.

Muchas fueron las experiencias que se pusieron en marcha, el desarrollo de variados e ingeniosos recursos a favor de los mayores y sus familias, ideas novedosas en la atención, fórmulas importadas y contextualizadas que se integraron sin más resistencia que el asombro por su funcionamiento. La huella de Tońo estaba ahí, y sorteando no pocas dificultades y contratiempos en ese desarrollo mantuvo desde el comienzo un apoyo incondicional a las enfermeras, a las que dio responsabilidades y competencias nunca antes vistas en la gestión de los centros asistenciales y alimentó su liderazgo en un plan asistencial multidisciplinar que vio claro, podíamos sostener. Las empoderó y lanzó "al ruedo". El tiempo demostró, ajenos a sinsabores, que había sido una decisión acertada, eficiente, rentable, segura y que todavía mantienen a gala. Fraguó junto a las enfermeras un modelo de atención residencial, en centros de día, rico, firme y duradero.

Tońo nos dejó el pasado mes de marzo, cuando apenas llevaba unos meses disfrutando de su merecido descanso laboral junto a Angelines y el resto de familia, ambicionando ya, alejado de la costosa cotidianeidad, alargar sus paseos, mecerse en la huerta, compartir su música, deleitar con amena conversación o enriquecerse del silencio recio del que sabe escuchar.

Sin duda me hubiera gustado despedirme en persona, pero no fue posible. Hoy, con su permiso, me he acercado de nuevo a él y aplaudido en esta pública plaza, valores humanos y profesionales de una gran persona, de un gran gerontólogo, que contra vientos y mareas creyó hasta el final en el potencial de las enfermeras que le rodearon y siempre, estoy seguro, le honrarán y recordarán.

Gracias amigo y hasta siempre 